\title{
PATENTS: JUDICIAL DEVELOPMENTS AND LEGISLATIVE PROPOSALS*
}

\author{
Sytvester Petro门
}

\section{THE HARTFORD-EMPIRE CASE AND COMPULSORY LICENSING}

$\mathrm{T}$

1HE use of patents as a means of dominating national and international industries has been widely discussed in the last few years. ${ }^{x}$ Congressional investigations, with a view to reforming the American patent system, recur perennially. ${ }^{2}$ Meanwhile, the Supreme Court has been attempting to piece together a doctrinal body of patent law compatible with the competitive economic system to which the United States is formally committed. As this comment is being written, the Court has under consideration an appeal from the district court for the northern district of Ohio. The case on appeal, Hartford-Empire Co. et al. v. United States ${ }^{3}$ besides supplying a rich vein of earthy information with which to evaluate the operation of the American patent system generally, also presents a number of interesting legal questions and one issue crucial in the developing body of patent-law doctrine-the issue of compulsory licensing.

The first part of this comment will be devoted to a somewhat detailed exposition of the history of the glass-container industry, the manner in which Hartford-Empire rose to domination of that industry, and the legal issues raised by the Hartford-Empire case. The facts and legal issues presented by the case will also serve as a background for the second part of this comment, in which recent legislative proposals for reform of the

* Part I. Part II of this comment will appear in the April issue of the Review.

† Of the I943 Board of Student Editors of the Review.

x Comprehensive bibliographies on patent law and the economic aspects of the patent system may be found in Bennett, The American Patent System (I943), and Wood, Patents and Anti-Trust Law (1942). See also: No Peace with I. G. Farben, Fortune Magazine ro5 (Sept., , 1942); Cartels; The Menace of World-Wide Monopoly, The New Republic, March 27, 1944 (supplement); Levi, International Cartels and the War, in Puttkammer (ed.) War and the Law 124 (1943); Berge, Cartels: Challenge to a Free World (I944).

${ }^{2}$ See Feuer, The Patent Privilege and the T.N.E.C. Proposals, I4 Temple L. Q. r80 (r940); Borkin, Patents and the New Trust Problem, 7 Law \& Contemp. Prob. 74 (I940); Wyss and Brainard, Compulsory Licensing of Patents, 6 Geo. Wash. L. Rev. 499 (r938). The bibliographies cited in note $x$ also refer to the relevant Congressional hearings.

${ }^{3} 46$ F. Supp. $54 \mathrm{I}$ (Ohio, I942); reargument in the Supreme Court ordered for October, x944, I3 U.S. Law Week 300 I (1944); 64 S. Ct. Ix4I (x944). 
patent system will be discussed and evaluated in the light of the requirements of a free-enterprise, competitive economic system.

\section{THE GLASS CONTAINER INDUSTRY ${ }^{4}$}

In I9O4 there were ${ }_{5} 5$ independent glass-container companies in America. In I923 the number had diminished to Ioo. By 1937 there were only forty. Of the forty, thirty-seven were licensees of Hartford-Empire, which means that their production was generally limited as to quantity, type, and market. ${ }^{5}$ The three remaining independents produced less than 4 per cent of all glass containers; and five of the thirty-seven licensees produced roughly 70 per cent of the total.

The basic cause of this shrinkage and centralization in the industry was the invention of mechanical means of forming, blowing, and cooling glass containers. Prior to I905, when Michael Owens developed a fully automatic machine for forming and blowing bottles, they had been made completely by hand and lung power. At present, less than I per cent is produced by hand.

Roughly speaking, the machine production of glass containers is a threestage process, employing a furnace, a former, and a cooling or annealing oven, called a lehr. ${ }^{6}$ After the constituent elements (silica sand, clay, etc.) have been reduced to a molten state in the furnace, the molten glass is molded according to the desired form, and then cooled gradually in the lehr. The two latter stages of the process are most important for present purposes, for the melting furnace has occasioned little if any dispute. The second or "forming" stage has been simultaneously the most litigated and the most important element in Hartford-Empire's rise to its dominating position in the industry.

4 The facts here narrated are derived either from the exhaustive opinion rendered by District Judge Kloeb, or from the equally exhaustive Temporary National Economic Committee (hereafter referred to as T.N.E.C.) hearings reported in Part 2 of the Investigation of Concentration of Economic Power. Discussions of the glass-container industry may be found also in: Barnett, Patent Property and the Anti-Monopoly Laws 333 et seq. (1943); Bennett, The American Patent System passim (r943); Hamilton, Patents and Free Enterprise tog et seq., T.N.E.C. Monograph No. 3 I (r94I); Wood, Patents and Anti-Trust Law I9I (I942); Note, Patents and the Anti-Trust Laws-The Glass-Container Industry, 53 Harv. L. Rev. II 73 (I940). It is interesting to observe how Mr. Barnett gilds the lily in his discussion of the glass-container case at 333-42, when even the most conservative of the other commentators, Mr. Wood, states: "Unquestionably the glass container industry has been the source of censurable practices. Nor can there be any serious question as to the illegality of many of the devices allegedly employed in attaining and maintaining the closely-knit industrial control." Wood at ror.

5 See United States v. Hartford-Empire Co. et al., 46 F. Supp. 54I, 592-93, 6I3 (1942); see also Part Two of the T.N.E.C. Hearings (hereafter cited as 2 TNEC) 402, 404 (I938).

${ }^{6}$ A useful description of the mechanical processes involved in the industry may be found in the appendix to 2 TNEC at 736 et seq. 
Until Igr7 Michael Owens' suction-type machine was without competition in the industry. The position of the Owens Glass Co., therefore, was the strongest in the industry; and its policy of highly restricted licensing, forcing many producers out of business, was probably responsible for the creation of a competing machine process. ${ }^{7}$

The Owens suction-type machine combined two operations-the feeding of the molten glass from the furnace and the molding or forming-in one device. The competing process, first widely used in $\mathrm{I}_{9 \mathrm{I}} 7$ and generally called the gob-feeding process, separated the feeding and forming operations, and a feeder was employed to carry the glass from the furnace to another device called a former. Owens' exclusive right to the suction process has never been seriously challenged, but the rights to the gob-feed process were highly confused and disputed from the beginning. Indeed, Owens had itself acquired some gob-feeding patents and licensed a few companies in their use. ${ }^{8}$

Among the disputes concerning the gob-feeding process, the one between Hartford-Fairmont and Empire Machine Co. (a patent holding company organized by Corning Glass Works) is of basic importance. Hartford and Empire had simultaneously submitted applications for patents on strikingly similar gob-feeding devices in 1916 , and the patent examiner declared an interference. Girded in their respective might, Hartford and Empire eyed each other-and decided to settle the conflict out of court. ${ }^{9}$ Accordingly, in I9I6, they agreed to share their patents. Hartford was to have the exclusive right to manufacture or to license others in the manufacture of glass containers; Corning, through Empire, was to have the exclusive right in the manufacture of specialty glass-electric light bulbs, and heat resistant and other types of pressed and blown glassware. This agreement was formalized in I922, when Hartford-Fairmont and Empire Machine Co. merged to form the Hartford-Empire Co., a nonmanufacturing patent holding company, whose sole official activities were developmental research and licensing..$^{\mathrm{x}}$

From this merger great things were expected. As early as IgI9, F. Goodwin Smith, general manager and, later, president of Hartford-Empire, felt that a merger between Hartford and Empire "would, within reasonable time, dominate the entire glass industry here in the States. ...." ${ }^{\prime \prime I}$

\footnotetext{
7 See Hartford-Empire Co. v.Hazel-Atlas Glass Co., 59 F. 2 d 399, 402,403 (C.C.A. 3 d, I932).

${ }^{8} 46$ F. Supp. 54 x at 548 .

ro Ibid. at 549 .

9 Ibid.

II Ibid. at 553 .
} 
As of 1922 , however, the "chaos" of the industry left much to be desired, from Hartford-Empire's point of view. Besides Owens' gob-feeder patents, there were outstanding rights in many other companies. Feeder rights were owned by Howard Automatic Machinery Co., William J. Miller Co., and the Federal Co. Outstanding patents or patent applications on the forming machine were held by the Cox Co., Sears and Lobb, Headley and Thompson, Ed. Miller and Co., the O'Neill Co., and the Lynch Forming Machine Co. Most objectionable, also, was the fact that glass producers could then purchase outright, without license restrictions, the lehrs manufactured by the Amsler-Morton Co. Finally, various important glass container producers, including Hazel-Atlas, the only producer approaching Owens in size and power, were operating or licensing smaller producers in the operation of machines of their own design.

This "disorder" was sufficient, without more, to make the industry seem generally unhealthy to Mr. Smith of Hartford-Empire. But for one in his position even a cursory glance at the panorama of the glass industry would result in a pathological fixation when it met Owens Glass Co., which stuck up like the Rocky Mountains, firm in financial and patent strength, and very jealous of its position. "There is no question in my mind," wrote Smith after a discussion with some of the Corning and Empire representatives in IgI9, "but what the Owens Co. will increase their efforts to attack our patents.... This will prove costly as regards litigation, and may prove costly as regards some necessary changes." ${ }^{22}$

It was obvious that anyone seeking to dominate the industry had from the start either to eliminate or to combine with Owens. Since elimination was out of the question, Hartford went to the mountain. After numerous conferences, Hartford and Owens entered into a written agreement in I924. ${ }^{\mathrm{r}}$ Under this agreement, Owens accepted Corning's sovereignty in the specialty field and agreed to suppress its own gob-feeding machinery. In return Owens was to receive one-half of Hartford's divisible income over $\$ 600,000$ annually from its licensees. In addition-a point of the greatest significance-section 22 of the agreement gave Owens a veto power over the extension of licenses to Hartford's machines. ${ }^{\mathrm{T}}$ By section 22, therefore, the strongest producer in the industry was granted the wherewithal to maintain its leadership: enterprisers anxious to enter the

$=2$ Tbid. at 554 .

${ }^{23}$ On the terms of this agreement generally, see ibid. at 549.

${ }^{14}$ Section 22 was abrogated in 193 I because of the worry it caused the Hartford officials. "The rest of our contract relations are pretty complex and pretty carefully safeguarded," wrote $H$. K. Smith of Hartford. "But section 22 stands out .... like a lighthouse, and would .... focus .... the attention of the .... Government." 46 F. Supp. 54 I at 598. 
industry would have to please Owens, and Owens' guiding concept was stabilization.

For Hartford-Empire the I924 contract was another step toward domination of the industry. It meant a greater certainty of royalty and license fees, moreover, for with Owens getting a share of the fees it would exercise its enormous power and prestige in persuading other producers to come under Hartford's wing. Needless to say, the other producers had no inkling that part of the license fees they paid to Hartford were going to their strongest competitor.

For Owens the covenant made possible a return to the comfortable security it had enjoyed prior to the advent of the troublesome gob-feeding patents. To everyone but Owens (and later, Hazel-Atlas) a license from Hartford carried with it production and territorial restrictions. So strong was Owens' desire for stabilization, security, and simplicity, ${ }^{15}$ that since I924, possibly because of a tacit understanding with Hartford, it has licensed no one in the use of its suction process. The stabilizing potentialities of its veto power outweighed the desirability of the fees realizable from licensing the suction process.

The articles of faith, consummated in the 1924 convenant, are well expressed in a memorandum by H. K. Smith of Hartford, dated April 22, I922:

.... The commercial considerations, involved in considering either an agreement or a conflict between Owens and H-F, are of greater importance than the relative patent values controlled by the two companies. By "commercial considerations" is meant the domination of outside feeders, the stabilization of the industry tending against irresponsible price-cutting; the general co-operation between the gob and suction processes for an orderly development of the two side by side, such as will be most beneficial to the interest of the two companies and to the industry; and finally the steadying influence that will be established in the machine side of the industry by a recognized co-operation between the two companies. ${ }^{16}$

This is a clear declaration that the patents per se were considered unimportant; they were important only in so far as they contributed to the "commercial considerations."

Having settled their differences, thenceforward Hartford and Owens jointly faced the task of cleaning up the industry. Their faith settled in the rock of the covenant (of 1924), they bent their gaze about them for their future constituency. They decided, after surveying the field, that their

15 Ibid. at 560 et seq.

${ }^{16}$ Tbid. at $56 r$.

17 See further, ibid. at 6 I $_{5}$. And see the discussion of the Ethyl case, text infra at note 47 et seq., for the legal consequences of this fact. 
aims would find most efficient realization through a pooling of their legal and financial strength. ${ }^{\mathrm{x}}$

By I924, Hartford had already purchased the important Howard feeder patents, but many other feeder patents were still outstanding. Together, then, Owens and Hartford set out to convert the remaining unfaithful, some of whom were willing and some obstinate; sooner or later, however, all saw the light.

The Miller feeder rights were purchased with funds contributed jointly by Hartford and Owens for $\$ 145,000$, and the Federal rights, similarly, for $\$ 1,600,000$. The licensees of these two companies followed the patents and became licensees of Hartford; becoming a licensee of Hartford meant, of course, strict observance of the tenets of stabilization. For the machines were never sold outright but only leased for a limited period, and if a lessee proved uncooperative the lease would not be renewed. ${ }^{x 9}$

The greatest opposition was offered by Hazel-Atlas, which company, by preaching the gospel of its own feeder patents, had developed a separate congregation. According to a letter written by F. Goodwin Smith in I932, if no deal could be made with Hazel-Atlas, there would be "loss of opportunity to stabilize industry as far as present competition goes. $O$ considers stabilization worth several hundred thousand a year." ${ }^{20}$ Clearly the conversion of Hazel-Atlas was worthy of the greatest concentration; for if Hazel-Atlas could be induced to come in, "the remaining outsiders would fold up and become Hartford licensees. ...."

Beginning in 1924 , therefore, Hartford and Owens, pooling their resources, brought successive infringement suits against Hazel-Atlas. The cost of this litigation was staggering; ${ }^{22}$ yet, even after a defeat in the circuit court of appeals, ${ }^{23}$ Hazel-Atlas contemplated an appeal to the Supreme Court because Mr. McNash, its president, was "well satisfied that the feeding device used by Hazel-Atlas Glass Co. was a mechanism entire-

18 Ibid. at 549.

20 Ibid. at 567.

xg Ibid. at $6 \mathrm{x}_{3}, 62 \mathrm{r}$.

$2 x$ Ibid.

2 The following interrogation occurred at the TNEC hearings:

"Mr Cox: Can you tell us what the legal expense was?

"Mr. McNash (President of Hazel-Atlas) : I believe it ran somewhere from 50 to I 50 thousand dollars a year" (for eight years). 2 TNEC 537.

The cost to Hartford was about $\$ 900,000.46$ F. Supp. $54 \mathrm{r}, 565$.

${ }^{23}$ Hartford-Empire Co. v. Hazel-Atlas Glass Co., 59 F. 2 d 399 (C.C.A. 3d, I932). Auguring the decline and fall of Hartford's empire, the Supreme Court has recently held that the decree in favor of Hartford-Empire be vacated because Hazel-Atlas, ninè years later, proved "conclusively" that Hartford's patent had been procured by fraud on the Patent Office, and the finding of validity in favor of Hartford was obtained by a fraud practiced on the circuit court of appeals by Hartford-Empire. Hazel-Atlas Glass Co. v. Hartford-Empire Co., 322 U.S. 238 (I944). 
ly of our own development. We saw no reason why someone should come in and attempt to control our use of that device."24

Hartford and Owens had no desire to put the case to the Supreme Court test, however, and the obvious desirability of having Hazel-Atlas as a friend persuaded them to make the belligerent an offer that could not reasonably be resisted. According to 'Mr.' McNash, Hartford "approached us in connection with taking a license.... under such conditions that .... we would have been foolish to refuse. ${ }_{25}$ Under the bargain, as it was finally formed, Hazel-Atlas agreed to pay Hartford royalties on machines which Hartford had never built, and in return Hazel-Atlas was promised one-third of Hartford's income from licenses and royalties over $\$ 850,000$, Owens agreeing to reduce its share from one-half to one-third. It was not a bad deal for Hartford and Owens, because the spirit of their compact was maintained: With the conversion of Hazel-Atlas the remaining opposition collapsed. Standing to gain each time Hartford acquired a new licensee, Hazel-Atlas became scarcely less diligent than its elders in spreading the faith. And many were the moans when it was revealed to the licensees that a share of their fees was going to Hazel-Atlas. ${ }^{26}$

With the conversion of the Hazel-Atlas congregation, Hartford and Owens were supreme in the feeder field. Simultaneously, and with rather less trouble, they gained control of the forming-machine patents. Hartford either purchased the outstanding rights, or, still with contributions from Owens, financed Lynch, the largest forming-machine manufacturer, in the purchase of them. In return, Lynch promised to sell forming machines royalty-free to all licensees of Hartford; anyone not a feederlicensee of Hartford, however, was charged royalty rates on the forming machine equivalent to those charged the feeder licensees. ${ }^{27}$

Thus, Hartford acquired practically complete domination of the feederformer processes, and in the meantime Owens had been perfecting its rights to the suction process. ${ }^{28}$ Anyone who wished to enter the industry had therefore to go to Hartford or Owens, or brave an infringement suit.

Until I934, however, there was still one stage in the machine production of glass containers over which sovereignty had not been established: patent rights in the cooling oven - the lehr ${ }^{29}$-were still unsettled..$^{30}$ Here

242 TNEC 537 . 25 Ibid. at 538 .

${ }^{26}$ See, for example, the testimony of R. R. Underwóod, president of Knox Glass Associates, at 2 TNEC 594 .

${ }^{27} 46 . F$. Supp. 54I, 550 et seq. $\quad{ }^{28}$ Ibid. at 550-5r, 6rg.

${ }^{29}$ See Hartford-Empire Co. v. Swindell Bros., Inc. (Amsler-Morton Co., Intervener), 96 F. 2d 227 (C.C.A. $4^{\text {th }}$, r938).

${ }^{30}$ See generally, 2 TNEC 596-602. 
Hartford had only one important competitor, the Amsler-Morton Company, which had been making and selling lehrs under a patented process since I9 5 . In 1926 Hartford first charged the Amsler-Morton people with infringing the Hartford lehr patents, and in I928 invited them to a conference. At this first conference, Mr. Smith of Hartford suggested that Amsler-Morton raise the price of its lehr from $\$ 9,500$ to $\$ \mathrm{I} 3,500$, in return for which Hartford would grant a cross license if the $\$ 4, \infty$ were paid to Hartford. Such a raise in price would put Amsler-Morton in a poor competitive position, however, so the proposal was rejected..$^{3 x}$

The next proposal from the Hartford and Owens interests was punctuated ominously. A delegation of Hartford licensees and Owens officials visited the Amsler-Morton people in February, I934, and urged them to merge with the Hartford lehr manufacturers. Hartford's best offer, made by Mr. Hazelton, the vice-president of Owens, was a one-third interest in the projected merger. This offer was rejected also, but as Mr. Hazelton rose to leave, he warned the Amsler representative thus:

If you don't go in with us on this thing, we will enter suit against you and we will continue to sue you until you are out of business..... It is our plan that nobody in the glass business should own one piece of glass-making equipment. ${ }^{32}$

And it came to pass even as Mr. Hazelton prophesied. Up to Ig28 Amsler-Morton had been thriving with an annual business of $\$ 800,000$; in I938 it did $\$ 18,000$ worth of business in the glass-container industry. Hartford's first step had been to threaten all Amsler-Morton customers with infringement suits. ${ }^{33}$ Then, in 1934, Hartford executed a maneuver which gives some insight into the feats possible under the present patent system. The Swindell Co., one of Amsler-Morton's customers, had purchased lehrs also from Hartford and had covenanted not to contest the validity of the Hartford patents. Meanwhile, Amsler-Morton had contracted with the Swindell Co. to step ințo the latter's shoes in any infringement suit concerning lehrs. Here, then, was a way to strangle Amsler-Morton without opening the always uncertain issue of priority as between the Hartford and the Amsler-Morton patents. If Hartford sued Swindell, Amsler-Morton would be forced to defend; and since it was stepping into Swindell's shoes, Amsler-Morton would be estopped from contesting the validity of the Hartford patents because Swindell had promised Hartford not to contest the validity of the latter's patents.

The fourth circuit court of appeals held that the Amsler-Morton lehr

${ }^{3 x}$ Tbid. at 597 .

32 Ibid. at 599 .

${ }^{33} \mathrm{Ibid}$. at 598. 
infringed the Hartford patents. ${ }^{34}$ The litigation cost Amsler $\$ 50,000$; but the most serious result was the shrinkage in business, owing largely to Hartford's circularization of the results of the suit against Swindell. Prior to I934 Amsler had been selling approximately twenty lehrs annually: in I934 it sold five; in I935, four; in I937, none; and in I938, one.

With the slow death of Amsler-Morton, Hartford's ambitions were realized. Domination of the glass industry was at hand, and the financial returns were great. In 193x, when the average corporation was losing money, Hartford's return on operating capital was approximately 4 per cent; in I932, Io per cent; in I933, I6 per cent; in I 935,23 per cent; in I936, 48 per cent; and in 1937,68 per cent. ${ }^{35}$

The fruits of domination were equally sweet for Owens. Of all Hartford's licensees only Owens was unrestricted with respect to the quantity and types of glass containers it could produce, though Hazel-Atlas, deserving the consideration of a minor prophet, had a somewhat comparable arrangement. In contrast to these favored peoples, some of the licensees were so restricted that they were virtually forced out of business. Knox Glass Co., for example, had been doing a thriving business producing Ioo-, $\infty 00$ to I 50,000 milk bottles annually before it became a Hartford licensee, but its license from Hartford set a quota of 75,000 annually. Finding it impracticable to work on that quantity with its organization and equipment, Knox Glass assigned its milk bottle rights to another company. ${ }^{36}$

Besides squeezing out such old producers as Knox Glass, Hartford and Owens also kept new capital from entering the industry. Having established their faith, these apostles guarded it jealously from desecration by infidels. Thus, when a group of Detroit businessmen, dissatisfied with the supply and price of glass containers in their city, approached Hartford for a production license (they had already purchased the equipment), the license was refused. ${ }^{37}$ The refusal was based ostensibly on the discouraging outlook of the industry, but there is some evidence that Hartford's refusal was caused by a fear that its relationship with Owens would be strained because Detroit lay in Owens' stronghold. ${ }^{38}$

The same situation obtained in Texas, where there are: a recognized shortage of milk bottles at reasonable prices; excellent natural facilities for the production of glass-containers; and no licensed producer nearer than the Liberty Co. in Oklahoma. Recognizing that \$IO.00 a gross for.

34 Case cited supra, note 29.

$35_{2}$ TNEC 798.

${ }^{6}$ For the full story on Knox, which is very interesting, see 2 TNEC $5^{82-96}$.

37 Ibid. 6rg-24."

${ }^{38}$ See testimony of George Day, ibid. at 623 . 
milk bottles in Texas was exorbitant when the price was $\$ 6.50$ in St. Louis, Knape-Coleman started production of milk bottles with one of the independently patented machines, when Hartford refused to grant a license..$^{39}$ Under threats of infringement suit, however, Knape-Coleman finally agreed to leave the industry. "I realized," Mr. Coleman said, "that we couldn't pay $\$$ IOO or $\$ 150$ a day to stay in the federal court." 40

The final piece in the pattern of domination and stabilization was the organization of a trade association, whose main functions since 1928 seem to have been the establishment of production quotas, indirect price-fixing, and the discouragement of capital seeking to enter the industry. ${ }^{4 x}$ The statistical committee of the association, the "breeding ground for hatching many of the conspiracies within the general conspiracy of dominance and control over the glass container industry," ${ }_{42}$ was composed of important officials of the largest producers in the industry.

Hartford's restrictive licensing, influenced by the demands of the favored producers ${ }^{43}$ on the one hand, and the activities of the trade association on the other, had thus succeeded in producing the monopolist's dream-an industry characterized by inflated stable prices, restricted output, and security for the producer, with efficiency only an incidental desideratum, and the most at the cheapest price for the public a sheer mockery.

This pre-emption of the laws of supply and demand, under the shield of the patent right, was condemned unqualifiedly in the district court of Ohio:

From the record in this case [Judge Kloeb stated], there can be no doubt that Hartford, at times ably assisted by its most favored licensees, .... determines and limits the law of supply and demand. This is beyond the right of any individual or corporation, and certainly goes far afield from the limited monopoly granted a patentee by virtue of his patent. ${ }^{44}$

39 Ibid. at 6ro-rg.

${ }^{40}$ Testimony of S. A. Coleman, ibid, at $6 I_{3}$.

${ }^{4}$ See 46 F. Supp. 54I, 585. One of the managers of the Glass Container Association, Emory G. Ackerman, wrote the following message to A. M. Pease of Hartford in I933: "Your thoughts tie in very closely with the thoughts we have had, and I have done a good deal of work during the last several years in an attempt to keep new plants out of the picture." Ibid. at 585-86.

${ }^{2}$ Judge Kloeb in 46 F. Supp. 54 I at 588-89.

43 The sub rosa influence of the favored producers on Hartford's licensing policies is amusingly revealed in the following letter written by a Hazel-Atlas official in 1933-after HazelAtlas had become the third member of the trinity: "It seems to me that when people like the Maywood Glass Company take up with the Hartford-Empire Company about the extension of licenses, that Hartford should certainly not write them and tell them they are referring it to the glass companies for decision; that is what they did in this case. This makes a lot of hard feeling among the competition [sic]." 46 F. Supp. 54I at $59 \mathrm{r}$.

44 Ibid. at 595 . 
Except for the tying agreement between Hartford and Lynch, which the court declared void under section 3 of the Clayton Act, the general censure was predicated on the theory that the patents were used in a way primarily. calculated, not to realize a reasonable reward for invention, but to achieve domination over the industry:

The entire history of the Owens-Hartford "partnership," from its formation .... to the present time, indicates an unholy alliance designed by the parties thereto to attain seifish objectives at the ultimate expense of the public. The primary purpose underlying the alliance was not merely to settle legitimate conflicts, Patent Office interferences or litigation in the courts, in the interest of efficient operation of the patents. The primary purpose was to achieve domination of the industry. ${ }^{45}$

While the patent monopoly is presumably granted in order to promote the progress of the useful arts, Hartford's practices served, Judge Kloeb felt, "to destroy initiative in promoting the progress of the arts and sciences." 46

Since $I 897$ the courts have held that patents may.not legally be used as a means of gaining domination over an industry. "Patentees may compose their differences, as the owners of other property may," one court has said, "but they cannot make the occasion an excuse or cloak for the creation of monopolies to the public disadvantage." 47 A combination resulting from such use of patents does not share the immunity of the patentee's legally granted monopoly, as another court has said, "for the reason that the restraint of trade or monopoly arises from combination, and not from the exercise of rights granted by letters patent." 48

The Supreme Court recently brought this view down to date in Ethyl Gas Corp. v. United States. ${ }^{49}$ Owning patents on a lead fuid which when mixed with ordinary gasoline produced an anti-knock fuel on which it also

45 Ibid. at 6 Ig.

${ }_{46}^{6} \mathrm{Ibid}$. at $6 \mathrm{r}_{5}$. In most Hartford licenses there is a condition that all improvements made by licensees become the property of Hartford. And according to a memorandum by H. K. Smith, among Hartford's main purposes in taking out patents were: ". . . . (b) To block the development of machines which might be constructed by others for the same purpose as our machines, using alternative means. (c) To secure patents on possible improvements of competing machines, so as to 'fence in' those and prevent their reaching an improved stage." Ibid. at $6 \mathrm{I} \mathrm{I}-\mathrm{I2}$.

47 National Harrow Co. v. Hench, 83 Fed. 36,38 (C.C.A. 3 d 1897 ). Compare the statement made in Standard Oil Co. v. United States, 283 U.S. I63, I74 (I93 I): "Iawful individual monopolies .... cannot be unitedly exercised to restrain competition." See note, Patents and the Anti-Trust Laws-The Glass Container Industry, 53 Harv. L. Rev. Ir 73, xI76, note 20 (I940).

$4^{8}$ Blount Mfg. Co. v. Yale \& Towne Mfg. Co., I66 Fed. 555, 562, (D. Mass., rgo9). See Havighurst, The Legal Status of Industrial Control by Patent, 35 IIl. L. Rev. 495, 5Io (I94r).

${ }^{49} 309$ U.S. 436 (I940). Compare the statement by Mr. Justice Douglas in United States v. Masonite Corp., 3 r6 U.S. 265, 277 (x942): "The owner of a patent cannot extend his statutory grant by contract or agreement. A patent affords no immunity for a monopoly not fairly or plainly within the grant." 
owned patents, Ethyl sold the fluid to refiners, and licensed those refiners to sell the resultant fuel only to jobbers licensed by it. These licensing arrangements, the government charged, were intended to, and did, operate as a price-fixing device; for licenses to jobbers were extended or withheld depending on whether Ethyl's investigators found that the "business ethics" of petitioning jobbers were such that they would not indulge in price-cutting or other "undesirable" marketing practices..$^{50}$

Stating that one patent could not legally be used to add to the restrictive power secured by another, the government argued that Ethyl's conduct came within the interdiction of the Sherman Act:

The appellant is not attempting to obtain any financial return from the mixing and use patents. It is attempting to use them solely for the purposes of dominating the marketing of lead-treated gasoline in the United States. This is an improper use of the patent privilege. $5 x$

The Supreme Court affirmed the decree of the district court dissolving the jobber licenses and reforming the refiner licenses. In part the affirmance was predicated on the well-established doctrine that one who has sold a patented article may not control its further marketing. ${ }^{52}$ But the Ethyl case is a most important precedent for the Hartford-Empire case because of the emphasis placed on the theory that licensing restrictions will be valid only when they are designed primarily to increase the return on or enhance the development of the patented object. Ethyl used its patents, the present Chief Justice said, "not as a means of stimulating the commercial development and financial returns of the patented invention which is licensed, but for the commercial development of the business of refiners and the exploitation of a second patent monopoly not embraced in the first." 53

The evidence in the Hartford-Empire case similarly reveals an intent to use the patents primarily as a means of gaining domination over the market. There can be little doubt, therefore, that the district judge's finding of an illegal restraint of trade will be sustained in the Supreme Court. ${ }^{54}$

${ }^{50} \mathrm{Ibid}$. at 453 et seq. $\quad 5 x$ Mbid. at 443 .

${ }^{52} \mathrm{Ibid}$ at 452, 457. Compare United States v. General Electric Co., 272 U.S. 476 (Ig26). See United States v. Univis Lens Co., et al., 316 U.S. 24x (x942).

53 Ibid. at 459 . Note the evidence in the Hartford case, supra at note 17.

${ }^{54}$ See $64 \mathrm{~S}$. Ct. xI4I (1944); reargument was ordered only with respect to the propriety of the terms of the district court's decree. Compare the prediction made in Patents and the AntiTrust Laws, op. cit. supra note 47 at II 79. It should be remembered also that control of quantity is an indirect price-fixing device, and the Supreme Court has recently stated that, "Any combination which tampers with price structures is engaged in an unlawful activity." United States v. Socony-Vacuum Oil Co., 310 U.S. 150, 221-23 (1940). See Havighurst, op. cit., supra note 48 , at 5 II.

Though it proposes a refinement, the holding here suggested for the Hartford-Empire case 
But the most hotly contested issue on appeal to the Supreme Court is certain to involve the remedy ordered by the district court.

Feeling it his duty to the public "to make such orders as .... [are] necessary and sufficient to remove the effects of the violation of the antitrust laws," "55 Judge Kloeb ordered a temporary receivership for HartfordEmpire, and dissolution if the receivership failed to restore a free and competitive status to the industry. And in addition to the cancellation of all existing agreements, leases, and licenses, the decree required that all the defendants (including Owens with its suction process), "license anyone, royalty free, in the manufacture of machines embodying the patent rights." 56

On and off for the past forty years, successive bills proposing compul- sory licensing under certain conditions have been submitted to Congress. ${ }^{57}$ Yet, despite the fact that the United States is the only industrial nation in the world without some sort of a compulsory licensing provision, ${ }^{58} \mathrm{Con}$ gress has consistently failed to act on any such proposal. This "legislative history," of coursè, is certain to be relied upon in argument for revision of Judge Kloeb's decree. ${ }^{59}$ In addition, no United States court has hitherto

does not necessarily overrule the General Electric case, 272 U.S. 476 (I926), which held that a patentee is entitled to fix prices at which his licensee sells the patented goods. Thus far the Supreme Court has refused to reconsider its holding in the General Electric case (See United States v. Univis Lens Co., et al., 3I6 U.S. 24 I [x942]), despite requests by the Department of Justice for such reconsideration. In view of the profound revision of the patentee's rights which would result from a complete overruling of the General Electric case, the hesitancy of the Court is understandable. Yet this justifiable hesitancy need not extend to a condonation of Hartford-Empire's restrictive licensing program, for the Hartford and General Electric cases are distinguishable. In the Hartford case the restrictive licenses were part of an explicit plan to dominate the glass-container industry. Under the suggested rationale of the Ethyl case, there fore, the Court may hold the Hartford licenses invalid without destroying the patentee's right to control the production of licensees except where such control is used as leverage to gain a domination not strictly within the purview of the patent grant-control over something outside the patented article or process. (See the statement by $\mathrm{Mr}$. Justice Douglas in note 49 , supra, and the adumbration by Mr. Justice Clarke, text infra at note 68.) Such a rule would still extend large rewards to inventors and would discourage only that class of financier whose support is conditioned on the hope of domination of an industry. Needless to say, the patent system is not designed to nourish that class of financier. A rule outlawing restrictive licensing under such conditions, therefore, would be consistent with the theory both of the antitrust laws and the patent laws. See notes 68 and $8 \mathrm{r}$, infra.

${ }^{55} 46$ F. Supp. $54 \mathrm{I}$ at $6 \mathrm{I} 7$.

${ }^{6} \mathrm{Ibid}$. at $62 \mathrm{I}$ (italics added).

57 See Wyss and Brainard, op. cit. supra, note 2. The latest such proposal was made in S. 249I, 77th Cong., 2d Sess., I942, a bill introduced by Senator O'Mahoney, Chairman of the T.N.E.C.

${ }^{58}$ See Wyss and Brainard, op. cit. supra, note 2, at 500.

59 See Barnett, Patent Property and the Anti-Monopoly Laws 342 (I943). Mr. Barnett thinks that if the Supreme Court affirms Judge Kloeb's decree, "it would be completely destructive of the patent system." This statement apparently means that unless patentees are allowed to use their patents to dominate industries, the patent system is worthless. 
decreed compulsory licensing; indeed, in a case squarely on point, a compulsory license was refused. ${ }^{60}$

Despite the absence of legislative sanction or judicial precedent, however, there is sufficient doctrinal development to justify affirmance of the district court's decree in the Hartford case. And since the restraints upon competition and the introduction of new capital, clearly evident in the history of Hartford-Empire's domination of the industry, arose from an abuse of the patent privilege and are repugnant to the spirit of the antitrust laws, the doctrines already developed should, and may with little real difficulty, be extended to affirmance of the compulsory licensing decree. The results of such a decree, as summarized by Judge Kloeb, should be welcome in a free enterprise economy: "Any newcomers who desire to go into the business of manufacturing shall be sold the necessary equipment, provided they have a proper credit rating..... Hereafter any manufacturer of glassware may produce any item he desires."6r

In certain cases, clearly, the only way to inject competition into an industry improperly dominated through the abuse of patents is by making those patents generally available to new competition. This necessity was expressly, though indirectly, recognized by $\mathrm{Mr}$. Justice Brandeis in the Oil Cracking case, when he said:

Unless the industry is dominated, or interstate commerce directly restrained, the Sherman Act does not require cross-licensing patentees to license at reasonable rates. ${ }^{62}$

The dominating position of Hartford-Empire in the glass-container industry satisfies the condition precedent to a decree of compulsory licensing as stated by Mr. Justice Brandeis. Yet, in order to show that compulsory licensing will do no violence to the underlying judicial developments in patent law, it is necessary to discuss the lower court opinions denying the availability of compulsory licensing as a remedy, and to trace some recent developments which completely undermine the present validity of those lower court opinions.

In the first of these cases, Radio Corp. of Am.v. Hygrade Sylvania Corp., ${ }^{6_{3}}$ the question of compulsory licensing was not at issue, for the case was an infringement suit in which the court held that violation of the anti-trust laws on the part of the plaintiff was no defense. (This doctrine, shaky in I934, is certainly not the law now, in view of the Morton Salt case, which

${ }^{60}$ F.A.D. Andrea Corp. v. Radio Corp. of Am., I4 F. Supp. 226 (D. Del., I936).

${ }^{6 \mathrm{r}} 46 \mathrm{~F}$. Supp. 54r, 62I.

${ }^{62}$ Standard Oil Co. v. United States, 283 U.S. I63, I72 (I93I)

${ }^{6}$ Io F. Supp. 879 (N.J., I934). 
will be discussed presently.) In disposing of the Hygrade case and the defense based in part on Mr. Justice Brandeis' statement quoted above, the court said, "There is no law that one who restrains trade forfeits one's property to any person who chooses to take it." ${ }^{34}$

Two years later another district court, in F.A.D. Andrea Corp. v. Radio Corp. of $A m .{ }^{65}$ squarely rejected a plea, based partly on the Brandeis statement, for compulsory licensing. Citing the Hygrade case, the court refused to decree a compulsory license because to do so would be to presuppose that a violation of the patent grant by a patentee worked a forfeiture of his patent privilege-the privilege arbitrarily to exclude all others from the use of the patented article. In addition, the court in the Andrea case held that the stated remedies under the Sherman Act are exclusive, and that, similarly, no general equitable remedies are available under the Clayton Act. The decision was based, then, on two propositions: first, that a patentee's right to his patent is not altered even though, under the law, he has misused that patent; and second, that there are no general equitable remedies (the compulsory license being regarded as the equivalent of a mandatory injunction) available under the anti-trust laws.

Actually, both propositions are unsound now and may have been so at the time that the Andrea case was decided. The case relied on for the second proposition was Geddes v. Anaconda Copper Mining Co. ${ }^{66}$ Far from holding that general equitable remedies are not available under the Clayton Act, that case held only that a mandatory injunction could not be decreed under the Clayton Act because in that case the necessary prerequisite to relief-monopolistic control-was not proved:

Upon the case here made by the evidence it is impossible to conclude that the defendants constituted in IgII such a combination ..... as would justify the granting of an injunction to the plaintiffs even under the provisions of $\S \mathrm{r} 6$ of the Clayton Act.67

As for the first proposition relied upon in the Andrea case in rejecting the plea for compulsory licensing, it was not a clearly sound statement of the law in 1936, when it was made, and is at the present time clearly unsound. A development started in the Supreme Court in I93I, and completed this year, has established the doctrine that a patentee who has abused bis patent privilege does forfeit his property; at least the federal courts will give him no relief in case of infringement.

The grant of a patent carries with it the exclusive right to make, to use, and to vend the patented article. The anti-trust laws declare illegal all ("unreasonable") contracts or combinations in restraint of trade. As is

${ }_{4}$ Tbid. at 883 .

${ }^{6} 5$ Cited supra, note 60.
${ }^{66}{ }_{254}$ U.S. 590 (I92x).

67 Ibid. at 595 . 
often said, the patent statute speaks the language of monopoly, while the antitrust laws speak the language of free competition. Faced with the patent and antitrust statutes, the federal courts haye had two major tasks: first, that of defining the patent privilege in a manner such that it can live in the same legal system with the antitrust laws; second, that of developing a remedy in cases of abuse of the patent privilege.

Execution of the first of these tasks has resulted in both the narrowing and the clarification of the patent right. It may be said generally, at the present stage of development in patents and antitrust law, that the patentee is restricted to practices which are designed primarily to further his interest in the patented article: wielding the exclusive patent right in a manner designed primarily to extend one's dominion over another product or a whole industry is an abuse of that right. The structure of this approach is to be seen in a statement made by Mr. Justice Clarke in I9I7:

A restriction which would give [the patentee] .... a potential power for evil over an industry .... is plainly void, because wholly without the scope and purpose of our patent lawes and because, if sustained, it would be gravely injurious to that public interest, which we have seen is more a favorite of the law than is the promotion of private fortunes. 68

Concurrently, the courts have been working on a remedy for abuse of the patent privilege. To date, the resultant "remedy" has actually become a forfeiture of the abused "right"-exactly the thing which the Andrea and the Hygrade cases held did not exist. Thus in Carbice Corp. of $A m$. v. American Patents Development Corp. ${ }^{69}$ the Court held that a suit for contributory infringement would not lie when the plaintiff-patentee had attempted to monopolize the sale of unpatented articles by using a license arrangement to tie such articles to the use of his patented article. Criticized

${ }^{68}$ Motion Picture Patents Co. v. Universal Film Manufacturing Co., 243 U.S. 502, 519 (I9r7) (italics added). See also Ethyl Gasoline Corp. v. United States, 309 U.S. 436, 457 (I940).

Mr. Justice Clarke's statement is especially significant because of its preoccupation with the scope of the patent grant. Those writers who object to recent trends in patent decisions (e.g., Barnett and sources cited by him) apparently fail to recognize that, even in the absence of the antitrust laws, there may be limits to the grant contained in the patent statute. The words, "the exclusive right to make, to use, and to vend" (a given patented article or process), do not of themselves convey to a patentee the message of flawless carte blanche to do or not to do with the patent as he sees fit. And since the legislature has left to the courts the task of defining the respective scopes of the patent and antitrust laws, there can be no valid complaint when the courts essay a definition which will put meaning into both statutes. See the memorandum prepared by C. J. Colville and reprinted in Part 8 of the Hearings before a Subcommittee of the Senate Committee on Military Affairs; Hearings on S. 702, 78th Cong., Ist Sess. 982, 991-92 (1943): "What these writers don't understand," Mr. Colville states, "is that while patents are a perfectly proper monopoly and inventions are items of the greatest use, there is terrific abuse made of these to an extent that requires correction." Ibid. at 992.

69283 U.S. 27 (I93I). Analyses of the development of the Carbice doctrine may be found in Wood, Patents and Anti-Trust Law 37, 73, passim (r942). 
at the time as a kind of stab in the back, ${ }^{70}$ the merit of this decision seems scarcely questionable now. Certainly a patent on $\mathrm{X}$ should give the patentee no right to monopolize $\mathrm{Y}$ or $\mathrm{Z}$.

The Carbice case has led to a clearer delineation of the scope of the patent right and to further development of a penalty for exceeding that scope. In two recent cases, the Supreme Court has made it clear that an extension of the patent privilege, in a manner inconsistent with the antitrust laws or contrary to the public interest in some other way, will result in a forfeiture of the patentee's right to recover for either direct or contributory infringement of his patent. In the first of these cases, Morton Salt Co. v. G. S. Suppiger Co., Mr. Chief Justice Stone phrased the issue as follows: ". . . whether a court of equity will lend its aid to protect the patent monopoly when [the patentee] is using it as the effective means of restraining competition with its sale of an unpatented article." $7 x$ Identifying free competition with the public interest, the Chief Justice held that the suit for direct infringement would not lie. "It is a principle of general application," he said, "that courts, and especially courts of equity, may appropriately withhold their aid where the plaintiff is using the right asserted contrary to the public interest." 72 In connection with the discussion of the Andrea case, supra, it should also be noted that, according to $\mathrm{Mr}$. Chief Justice Stone, general equitable remedies are available under the Clayton Act. ${ }^{73}$

The second of these cases denying the patentee recovery is Mercoid Corp. v. Mid-Continent Investment Co., ${ }^{74}$ decided in January, I944. While assuming that the defendant was a contributory infringer "and that [the patentees] could have enjoined the infringement had they not misused the patent,"75 the Court nevertheless denied the relief sought. "In whatever posture the issue may be tendered," said Justice Douglas in speaking for the majority, "courts of equity will withhold relief where the patentee and those claiming under him are using the patent privilege contrary to the public interest." ${ }^{6}$ One final statement in the Mercoid case should be noted because of its bearing on the probable outcome of the Hartford case in the Supreme Court. In discussing the scope of equitable relief in cases involving the public interest, Mr. Justice Douglas said:

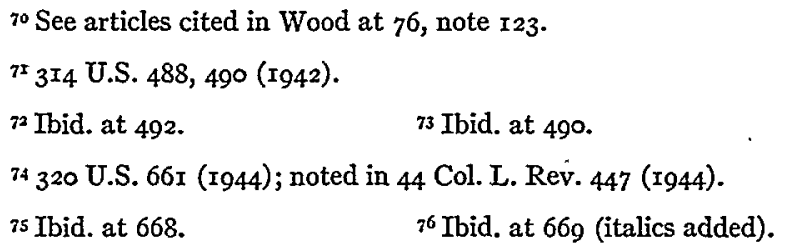


.... the determination .... of policy is not "at the mercy" of the parties .... nor dependent "on the usual rules governing the settlement of private litigation. "Courts of equity may, and frequently do, go much farther both to give and withhold relief in furtherance of the public interest than they are accustomed to go when only private interests are involved."77

Taken together, the Morton Salt and the Mercoid cases seem to identify competition with the public interest; they declare a forfeiture of the patent privilege when it is used contrary to the public interest; and they indicate that the Court is willing to use its power of issuing mandatory injunctions when the public interest is concerned.

The Clayton Act, as Mr. Chief Justice Stone suggested in the Morton Salt case, empowers the federal courts to extend general equitable remedies in cases "of threatened loss or damage by a violation of the antitrust laws." ${ }^{78}$ Such loss or damage is threatened by the situation in the glasscontainer industry. A compulsory licensing decree is the equivalent in the patents field of the mandatory injunction, and the general rule is that a mandatory injunction, like other tools of equity, is exercisable within the "sound discretion of the court."79 The present Court has held, moreover, that cases involving patent abuses which are simple and innocuous in comparison with the complex and far-reaching abuses in the glass-container industry, are cases involving the public interest. ${ }^{80}$ On the basis of these facts and the foregoing analysis, it seems clear that the developing theory in patent law will not be distorted, but will instead be clarified and further shaped, by affirmance of the district court's compulsory-licensing decree in the Hartford-Empire case. ${ }^{8 \mathbf{r}}$

Even the royalty-free aspect of the decree may be sustained without valid objection. For under the rule of the Morton Salt case, a patentee who has abused his privilege is denied equitable relief against infringement; hence, in view of Hartford's conduct, anyone inclined to enter the industry could

3 Tbid. at 670 (italics added), citing Virginian Ry. Co. v. System Federation, 300 U.S. 5 I5 (1937), a case in which a mandatory injunction was decreed.

${ }_{78}$ The Clayton Act, 38 Stat. 737 (1914); $\times 5$ U.S.C.A. $\$ 26$ (194I).

79 Morrison v. Work, 266 U.S. 48x, 490 (I925). See also United States v. Swift \& Co., 286 U.S. I06, II 4 (I932); Virginian Ry. Co. v. System Federation, 300 U.S. 5 I5, $55^{2}$ (I937); Berge, Remedies Available to the Government under the Sherman Act, 7 Law \& Contemp. Prob. I04, 105-106 (1940).

${ }^{80}$ See Zlinkoff, Monopoly versus Competition, 53 Yale L. J. 5I4, 516 et seq. (1944).

${ }^{81}$ The commonly voiced objections to compulsory licensing are that it would either discourage invention or make capital hesitant to support the exploitation and marketing of new inventions. See Bennett at $24 \mathrm{x}$ and Wood at $\mathrm{I} 95$ for representative arguments. Neither objection is valid when compulsory licensing is maintained only as a remedial device, to be used in cases where a "patentee" has paralleled Hartford-Empire's use of patents. See notes 54 and 68, supra. Reserved for such cases, the remedy is immune to any honest objection for the further 
use Hartford's patents without fear of restraint. In this light, the decree takes little from Hartford not already taken by the rule of the Morton Salt case; Hartford is not greatly abused by the royalty-free compulsory licensing decree. And in view of the fact that the patent is a peculiar type of property interest, granted by the public to an individual in the hope that it will advance the public weal, there is no injustice in revoking that interest when it has been used in a manner harmful to the public.

It should be said, finally, in accordance with Judge Kloeb's opinion, that when such an extensive skein of control as Hartford-Empire's has been achieved through the manipulation of patents, nothing less than the root-seeking changes proposed by the decree in the district court seems adequate to the restoration of free competition. The hydra-like history of combinations in restraint of trade indicates that if the aims of the Sherman Act are to be pursued seriously, something more than pious hopes and $\$$ Iooo fines is necessary.

\section{THE HARTFORD-EMTPRE CASE IN THE SUPREME COURT*}

The Supreme Court's decision in Hartford-Empire Co., et al. v. United States $^{82}$ was announced on January 8 , I945. This is a review of the majority and dissenting opinions.

In passing upon the propriety of the terms of the district court's decree, the Supreme Court stated that the severe characterization of the glass container cartel by District Judge Kloeb was completely supported by the evidence. Writing the opinion for the majority, Mr. Justice Roberts said: "The findings are full and adequate and are supported by evidence, much of it contemporary writings of corporate defendants or their officers

reason that it neutralizes, in some degree, the vast power of large business aggregations to intimidate smaller firms by threats of expensive litigation. Nothing seems more ridiculous than the complaint that the trends here discussed put "business" at a terrible disadvantage because they make available the "inexhaustible" funds of the government for litigation purposes. In the first place, it is of course not true that the antitrust division, for example, is above budget worries; in the second place, this concern with the effect of litigation costs on "business" reeks with hypocrisy when voiced on behalf of organizations which are in a position to dominate an industry partly because they themselves are able to use litigation as a threat. See Mr. Hazelton's pronouncement to Amsler-Morton at note 32, supra.

* Since the decision in the Supreme Court was announced after the foregoing comment was in page proof, integration of this review into the comment was not attempted.

${ }^{82}{ }_{323}$ U.S. - (I945); 13 U.S. Law Week 4122 (1945). The majority opinion, written by Mr. Justice Roberts, was concurred in by Mr. Chief Justice Stone, Mr. Justice Frankfurter, and Mr. Justice Reed. Mr. Justice Black and Mr. Justice Rutledge dissented in separate opinions; and Mr. Justice Douglas, Mr. Justice Jackson, and Mr. Justice Murphy took no part either in the consideration or decision of the case. A generalized statement of the terms of the district court's decree may be found in the opinion below, 46 F. Supp. 541 (Ohio, 1942). 
and agents."83 This affirmance of the district court's findings actually amounts to one of the most biting indictments of inter-corporate misconduct to be found in judicial literature.

Yet the Court's revision of Judge Kloeb's decree, which had aimed, as the antitrust laws require, to restore a free and competitive status in the industry; considerably limits its scope.

The decree framed by the district court had required, among other things, that the defendants license, royalty-free, all applicants who desired to make or use machines covered by any of the patents presently owned by the defendants. The Supreme Court recognized that the Sherman Act "authorizes an injunction to prevent continuing violations by those acting contrary to its proscriptions," but the majority opinion nevertheless decided that the remedy prescribed in this paragraph of the decree was too drastic. Mr. Justice Roberts premised that the Court "may not impose penalties in the guise of preventing future violations"; that, moreover, it "may not create, as to the defendants, new duties, prescription of which is the function of Congress. ...."84 Continuing, with specific reference to the provision of the decree under consideration (paragraph 24 [a]), $\mathrm{Mr}$. Justice Roberts echoed the belligerent complaint of Hartford's counsel, John T. Cahill, Esq., who, in the oral argument before the Supreme Court last fall, had said: "The provisions of this decree are a thinly disguised replica of the Department of Justice's recommendations to the TNEC, which in turn the TNEC recommended to Congress, and were rejected by Congress." ${ }^{85} \mathrm{Mr}$. Justice Roberts' version of this argument was: "Congress has not adopted such legislation. The Temporary National Economic Committee recommended imposition of such a penalty [forfeiture of patents] for violation of antitrust laws. But its recommendation was not adopted by Congress."

Thus the revision of the decree below becomes something of a crusadethe evil of judicial legislation is to be exorcized. Actually, however, a good case can be made out for the position that the district court's "drastic" decree is simply a courageous application of legislative intent as expressed in the antitrust laws. Or, on the other hand, if it be insisted that the dis-

${ }^{8} \times 3$ U.S. Law Week 4 122, 4124.

${ }^{84} \mathrm{Ibid}$. at $4 \mathrm{r} 26$.

${ }^{85}$ Transcript of oral argument before the Supreme Court, October 9-ro, I944, in HartfordEmpire Co., et al. v. United States 29 (mimeo. by the Master Reporting Co.). Mr. Cahill urged revision of the decree below in part on the ground that affirmance would mean the "death" of Hartford-Empire. And the death of Hartford-Empire, he implied, would be a blow to free enterprise and free competition. Ibid. at $15,21,26,30$, et seq.

${ }^{86}{ }_{13}$ U.S. Law Week 4 I22, 4 I28. 
trict court had "legislated from the bench," the Supreme Court's revision does no less.

The Sherman and Clayton Acts, it should be remembered, authorize injunctive relief both to prevent and to restrain violations of the antitrust laws. ${ }^{87}$ In a seldom-discussed section, moreover, the Sherman Act provides:

- Any property owned under any contract or by any combination, or pursuant to any conspiracy (and being the subject therof) mentioned in section $\mathrm{I}$ of this act, and being in the course of transportation from one State to another, or to a foreign country, shall be forfeited to the United States, and may be seized and condemned by like proceedings as those provided by law for the forfeiture, seizure, and condemnation of property imported into the United States contrary to law. ${ }^{88}$

Sections 4 and 6 of the Sherman Act and sections I 5 and $x 6$ of the Clayton Act, taken together, thus seem to indicate that the Congress had intended to put some teeth in the antitrust laws; they seem to authorize quite drastic remedies. The district court may have operated well within its powers, therefore, and as a matter of fact the majority opinion nowhere expressly states the contrary.

Indeed, the alteration of the decree inserted by the Supreme Court itself bears a strong resemblance to some of the ill-fated recommendations of the T.N.E.C., which had provided for compulsory licensing of patents at reasonable royalties in certain circumstances. ${ }^{89}$ For while the Supreme Court deleted the royalty-free feature of the district court's decree, it retained the compulsory-licensing feature; though the defendants are now required to license all applicants, they may still assess "reasonable" royalties. The revision also approves the compulsory licensing feature with respect to some future patents as well as those patents presently held by the defendants:

Paragraph 24(a) of the decree should be modified to permit the reservation of reasonable royalties and its provisions should be restricted to feeders, formers, stackers

${ }^{87}$ Section 4 of the Sherman Act reads, in part: "The several district courts of the United States are hereby invested with jurisdiction to prevent and restrain violations of this act; and it shall be the duty of the several district attorneys of the United States, in their respective districts, under the direction of the Attorney General, to institute proceedings in equity to prevent and restrain such violations. Such proceedings may be by way of petition setting forth the case and praying that such violation shall be enjoined or otherwise prohibited. ...." See also sections $I_{5}$ and 16 of the Clayton Act.

${ }^{88}$ Section 6 of the Sherman Act.

${ }^{89}$ See S. 249x, 77th Cong., 2d Sess. (r942), a bill introduced by Senator O'Mahoney, Chairman of the T.N.E.C., which provided in section 2 for compulsory licensing at reasonable royalties when a patentee fails to use himself, or refuses to allow others to use, a patented invention, and "such failure or refusal has resulted or is likely to result in a violation of the antitrust laws, or is otherwise detrimental to the public interest. ...." Compare Final Report and Recommendations of the Temporary National Economic Committee, Sen. Doc. No. 35, p. 36 (I94I), 77th Cong., Ist Sess. (I94I). 
and lehrs and patents covering these'or improvements of them, or methods or processes used in connection with them.90

If it is present at all, then, the specter of judicial legislation haunts the Supreme Court's decision, as well as the district court's decree. On the other hand, if the Supreme Court was only executing the mandate of the antitrust laws, so too was the district court. And from this, one can only conclude, with Mr. Justice Rutledge (dissenting), that the Supreme Court has substituted its discretion for that of the district court. This substitution occurred at many points, the most important of which will be briefly summarized.

In line with its revision of the compulsory licensing provision, the Supreme Court also revised that aspect of the decree (paragraph 29) requiring non-restrictive, non-exclusive licensing of all present and future patents held by the defendants. "Paragraph 29," Mr. Justice Roberts stated, "should be amended to permit any appellant .... to retain and refuse to license, to use and refuse to license, or to license with restrictions, any patent hereafter applied for or acquired except those applicable to feeders, formers, stackers and lehrs and processes and methods applicable thereto." 92

Paragraph 5I of the district court's decree, reduced to its essentials, had prohibited the acquisition of further patents by the defendants otherwise than by their own invention; it was probably aimed at preventing the defendants from reinforcing their patent position in the future, as they had in the past, by wholesale purchases and assignments from their licensees or competitors. The Supreme Court made short shrift of this provision: "The paragraph should be deleted."

Again, the Supreme Court pushed the district court's hesitancy to dissolve Hartford-Empire into a holding that the receivership ordered by the district court should be terminated, dissolution forbidden, and the business returned to its former managers. The Court nowhere stated that either the receivership or, indeed, dissolution, was or would have been an abuse of discretion. It merely said that they "were not necessary to the prescription of appropriate relief."93

The last of the more noteworthy revisions is the one concerned with interlocking directorships and financial interests. Judge Kloeb had prohibited either the corporate or individual defendants from holding practically any kind of interest in "more than one corporation engaged either

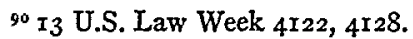

9x Ibid. at 4I 29-30 (italics supplied).
${ }^{92}$ Id. at $4 \mathrm{I} 3 \mathrm{I}$.

93 Id. at 4 I 27 . 
in the manufacture and sale of glassware or in the manufacture or distribution of machinery used in the manufacture of glassware or both." 94 Mr. Justice Roberts felt that this provision would (unwisely) prohibit interests even in noncompeting companies. He said, moreover, that the injunction against ownership even of bonds was unnecessary because "it is difficult to see how such ownership in any reasonable amount by any of the individuals in question could tend towards a violation of the Sherman Act."95 The alteration of this part of the decree is as follows: "The decree should be modified to prohibit acquisition of stocks or bonds of any corporate appellant by any other such appellant, and to prohibit only the acquisition of a measure of control through ownership of stocks or bonds or otherwise, by any individual in a company competing with that with which he is officially connected or a subsidiary or affiliate of such competing company." 96 Interlocking directorates were prohibited only to a corresponding extent.

Three of the points made by the dissenting Justices, Rutledge and Black, in criticism of the majority holding, seem particularly worthy of consideration.

First.-Mr. Justice Rutledge felt that the trial court was in a better position to estimate what measures would be necessary to erase the effects of the illegal combination, as the Sherman Act requires, and to prevent its recurrence; and since the Supreme Court found no illegality in the prescriptions of the trial court, Mr. Justice Rutledge continued, it should not have revised the decree:

Such an invasion of the trial court's function, it seems to me, perverts both that function and our own. If that court's findings, justifying the receivership and the reservation of decision on dissolution, were contrary to the law or the evidence, that should be demonstrated and declared. If they constituted an abuse of judicial discretion, the nature and character of the abuse should be pointed out. If they were neither, this Court goes beyond its province by substituting its own long-distance judgment for the immediately informed view of the District Court.97

Second.-Mr. Justice Rutledge also observed that the majority's view "ignores the momentum inherent in such a combination." tion, in effect, of many of the powers held by the combination prior to the suit, plus allowing the competitive advantage to be derived from the continuing receipt of royalties, were not, according to Mr. Justice Rutledge, measures designed to erase the effects of the combination and to prevent its recurrence:

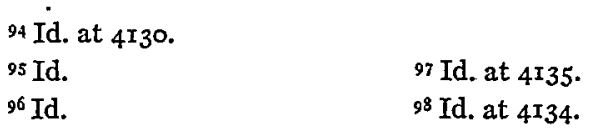


To permit these patents to remain in the guilty hands, as sources of continuing lucrative revenue, not only does not deprive their owners of the fruit of their misconduct. Rather it secures to them its continued benefits. The pool may no longer utilize illegal methods. It, and the constituent members, will continue to enjoy the preferred competitive position which their conduct has given them and to use both that position and the ill-gotten patents, together with the patent position, to derive trade advantage over rivals and gain from the public which the patent laws of themselves never contemplated and the anti-trust laws in my opinion, forbid. ....99

If [the royalty-free aspect of the decree] is drastic, it is because the violation was drastic and there is no other way now, short of dissolution or cancellation, to cut off its continuing effects of disadvantage to the public and the industry or of benefit to the violators. The court, seeking to avoid dissolution, had the duty to apply a remedy equally adequate.....

This Court's revision of the decree in this respect loads upon the industry and the consuming public continuing charges in favor of those who have violated both the anti-trust statutes and the patent laws, a burden which will not end until the last of the illegally aggregated patents has expired, if then.... . So to perpetuate the unlawful consequences of violation will not discourage, it can only encourage setting the law at naught. ${ }^{\text {or }}$

Third.-A further criticism of the majority opinion is suggested by $\mathrm{Mr}$. Justice Black. This criticism is not a "legal" one, but it has its merits. It is simply this: that the conspirators have escaped with relatively mild treatment; milder, indeed, than they themselves seem to have expected. In a memorandum drawn by one of Hartford's officers in I925, the following reference to possible prosecutions under the Sherman Act was made:

Of course, the court might order that we transfer the entire Federal licensing business to some other party and turn over to that party the Federal patents. This, of course, would simply restore to a certain extent the existing situation and establish a competitor..... I.... do not see much danger of having any of these deals upset. .... If they are upset, I still believe that by that time, we will be in a better position even with such dissolution than we would be otherwise. .... ${ }^{\text {xoz }}$

99 Id.

sor Id.

${ }^{100}$ Id. at 4136.

${ }^{102}$ Quoted by Mr. Justice Black, id. at 4r33. 